\title{
Discussion on Problems and Countermeasures in the Joint Responsibility of Civil and Commercial Law
}

\author{
Xisan Qi \\ School of Nanyang Institute of Technology, Grammar school, Nanyang, Henan 473000, China.
}

Keywords: civil and commercial law; joint responsibility; common problems; solutions

Abstract: The content of civil and commercial law is closely related to people's production and life. It can be described as the closest law to the people's livelihood issue. The relevant content of joint liability in the people's livelihood law is extremely critical. Many contents of the civil and commercial law have specific requirements for joint and several liabilities, and relevant regulations have been made. However, China still lacks the legal norms that only deal with joint and several liabilities. At the same time, there are relatively few researches and discussions on the joint responsibility of Chinese legal scholars. Therefore, the author believes that it is especially necessary to elaborate on the issues related to the joint liability of civil and commercial law, analyze the problems existing in the joint responsibility and propose corresponding solutions.

\section{Introduction}

The joint responsibility of China's civil and commercial law is one of the most important systems. Its significance is mainly to provide relief and compensation to the victims, to reflect the application value of the people's livelihood law, and to provide protection for the legal liability of the parties. It is worth mentioning that at present, the joint and several liability laws and regulations in China's civil law still have various problems, and it is difficult to achieve the original purpose of responsibility legislation. The author mainly focuses on the relevant provisions of the law, combined with practical work experience, and summarizes the current application of civil and commercial law. The issue of joint responsibility has also raised corresponding opinions and reflections.

\section{The concept of joint responsibility of civil and commercial law}

\subsection{Joint responsibility factors}

In the process of division and confirmation of joint liability, the following factors must be met in order to be considered as joint liability. First, the relationship between the debtor and the creditor is inseparable and inseparable, and the species in the joint responsibility object is the object. Second, the form of joint responsibility must be realized under the agreement of the parties and under the legal conditions. Third, there should be two or more debtors. Fourth, in line with the infringement conditions, in the actual event, the debtor's behavior has obvious illegal characteristics, and there is 
already a physical damage behavior. At the same time, the case reflects the causal relationship, and one party has economic loss behavior, and the above conditions can be confirmed as Joint responsibility [1].

\subsection{The concept of joint relationship}

The joint liability in the People's Livelihood Law refers to two or more parties, combined with relevant laws and regulations, and completed the agreement by time, jointly fulfilling the debt, or being undertaken by some people. The civil liability arising from its internal important relationship is often defined as the people. Commercial law is jointly and severally liable. If the debt incident involves multiple responsible persons, then any one of the responsible persons has the responsibility to pay off the debts, and the relationship between each responsible person is called a joint relationship.

\section{The problems of joint responsibility in civil and commercial law}

\subsection{The lack of fairness in the determination of joint responsibility}

China's laws and regulations have formulated joint and several liabilities, the main purpose of which is to avoid risks as much as possible, and to protect economic interests, and provide relief accordingly, so that economic transactions can be carried out smoothly. However, in legal practice, in many cases, the determination of joint responsibility is unfair, and the emphasis on external rights relief is emphasized. The excessive emphasis on external linkages neglects the importance of share division, often because of the unfairness of joint responsibility. The recovery work is extremely difficult [2]. Especially in the commercial field, bill guarantees and purchase and sale guarantees exist in a wide range. Although joint liability provides legal protection for the legal creditor relationship of creditors, it should be noted that the court usually does not have the responsibility of the guarantor and the creditor's responsibility. Clearly divided, or meticulous judgment, usually through the way of general judgment, directly determine the joint responsibility of the relevant personnel. In this process, in addition to creditors, guarantors often do not have the ability to repay debts. If the debtor disappears or is unable to repay the debt, then the creditor's claims will be difficult to obtain effective relief. Although there will be liability recovery within the joint and several liabilities, the protection of the creditor under the first condition will be hindered, and the recovery work in the future will inevitably become more difficult [3].

\subsection{Joint responsibility lacks system construction}

The civil and commercial legal provisions stipulate the scope of application of joint and several liabilities, but from a global perspective, there is still a lack of systematic division and clear regulations on the applicable conditions of joint liability in China's legal system. If there is no uniform norm, then the law will be enforced. It will be weakened to a certain extent. At the same time, there will be errors in the understanding of the concept of joint liability among parties, judges and lawyers. Taking the content of Article 60 of the General Principles of Civil Law as an example, it clearly stipulates that: "The power of attorney is not clear, the third party's creditor's rights are protected by law, the agent is responsible for the responsibility, and the agent is jointly and severally liable" [4]. This legal stipulation mainly addresses the relationship between the joint liability of the agent and the relationship between the responsibilities of the agent. On the surface, the joint liability requirement of the debtor has been specified under the condition that the authorization of the power of attorney is unknown, but the authorization is not known. The specific scope of application is 
fully explained. In this process, different subjects will have different understandings. In short, although our legal norms have been stipulated for joint liability, if there is no systematic norm of joint responsibility, and in detail, then the joint responsibility determination in legal practice will inevitably lead to bias in the direction, resulting in unclear final verification results [5].

\section{Recommendations to improve the joint and several liability application}

\subsection{Joint liability under the conditions of the enforcement of the procedural law}

Civil and commercial law is an important component of substantive law, and the application of joint liability in civil law is mainly embodied in substantive law. Its role is self-evident. In theory, the division of joint responsibility does not only mean that the actual implementation process will All work is carried out in accordance with the legal content. Therefore, in this process, law enforcement must be strict, and the legal requirements must be truly implemented in order to reflect the actual value of the law. Then how to ensure the execution of joint and several liabilities, at this time the procedural law should be introduced into joint responsibility to ensure the normal progress of subsequent implementation [6].

When the court determines the joint and several liability relationships, the parties usually combine the provisions of the substantive law with the special provisions of the procedural law for the joint liability system, and clearly define the division of responsibility in the substantive law to provide for the procedural law. The corresponding legal guarantee. For example, in the process of determining joint and several liabilities, it is necessary to clarify the subject to be executed. If there are multiple creditors in the case, the obligations of different creditors will be differentiated. In the civil procedure law currently in force, Article 53 clearly stipulates that if the parties have a common obligation or right to the litigation, the litigation is recognized by other litigants. In this case, the litigant against other joint litigants the effectiveness of the joint liability under these conditions is in accordance with the procedural law [7].

\subsection{Formulating joint and several liability mechanisms}

The joint liability in the civil and commercial law can be said to be an important way of responsibility. It can affect the application of laws and regulations, and it also has a balanced effect on the interests of the parties. In addition, it can indirectly alleviate social conflicts. To make the relationship between people more harmonious and progressive. To formulate a sound joint and several liability mechanisms, it is necessary to clearly agree to the scope of application of the responsibility, and to give the conditions for the application of the responsibility. The joint responsibility for different themes needs to be unified planning, which greatly improves the legal application effect.

Firstly, divide the joint responsibility boundary from a global perspective, and then identify its concept.

Secondly, the risk is applied to the implementation of the joint responsibility process, and a follow-up risk mechanism is established.

Thirdly, clarify the specific scope of joint and several liabilities, elaborate specific conditions, and stipulate uniform implementation principles.

\subsection{Taking the external joint as the main body and assisting the internal share judgment form}

In the legal relationship of one-way external creditor's rights, when determining joint and several liabilities, we should first start from the perspective of external recognition and do a good job of 
dividing internal share responsibility and give full attention. Under normal circumstances, different obligors will have applicable internal recovery agreements with each other. The efficiency and enforceability of this agreement are uncertain. In legal practice, the court should give high priority to prevent implementation confusion and unenforceable implementation. problem. For example, in the case of a large-scale commodity sales guarantee, when determining the guarantor's joint responsibility relationship, it is necessary to first understand the relationship between the guarantor and the guarantor and the actual agreed content, and then further examine it after general control [8].

Theoretically speaking, there is an internal agreement between the debtor and the guarantor, and the content of the agreement may violate the principle of the court not ignoring the law. Therefore, how to protect the legitimate rights and interests of creditors is a problem that needs to be solved urgently. The theory in this process Balance and practice still need to be further explored.

\subsection{Formulating realistic rules and regulations for the legal requirements of the parties}

In the legislative process, the relevant designers of the proceedings should, in conjunction with the legal requirements of the parties, carry out targeted design and rulings, analyze them from the perspective of legislation, and provide more institutional space for their needs. The first condition requires the legislator to start from the perspective of legislative justice, embody the fairness of litigation and systematic analysis. Based on this, the maximum value of the litigation benefit value can be realized as much as possible. After that, with reference to the specific situation, reference is made to the civil and commercial law. Responsible litigation procedures require the completion of specific design work in conjunction with the content of the system. Not only that, after the completion of the design of the procedural law system, in the next procedural legislative work, it should also apply practical solutions according to the specific circumstances to maximize the protection of the legitimate rights and interests of the parties. After the above requirements are met, it is also necessary to consider whether the procedural provisions in the substantive law meet the specific provisions.

\subsection{Identifying the responsibility of the joint infringer}

Too many infringements will cause various problems. At this time, we can refer to the content of the Tort Law, use it as the responsibility identification standard, effectively classify the specific responsibility of the infringer, and then combine the situation of the joint litigation to effectively its nature. If the case involves more people than the standard and the case is more serious, then all parties should sue at the same time. Under the premise of the joint lawsuit, the court must hear the case. If the creditor cannot sue at the same time, the court will not be able to hear the case. It is worth mentioning that, for the objective situation is more special, the debtor involved can carry out part of the litigation. Such a litigation model must be effectively judged in conjunction with the degree of involvement of the joint debtor. Not only that, but also the actual case should be used for prosecution, especially for implicated Serious part of the responsible person should ensure the accuracy of the judgment result [9].

\subsection{Completing the joint and several liability treatments in light of the actual situation}

At present, there are relatively many types of joint and several liabilities involved in civil and commercial law. Therefore, for different joint and several liability issues, it is necessary to make the most reasonable judgment based on the actual situation of the case.

For example, when dealing with the joint liability of a partnership-type joint venture, the parties 
usually combine the capital contribution ratio, fulfill their obligations or enjoy the rights. In this case, the court judgment needs to combine the proportion of the joint responsibility and judge them according to the specific circumstances. The actual responsibility that should be assumed. If the case involves joint and several liabilities, the judge must investigate the case in advance and determine which party the guarantee belongs to, whether it is a joint liability guarantee or a general guarantee. In addition, the scope of the guarantee should be clearly defined. The content of the legal provisions should be as meticulous and rigorous as possible. The joint liability for the parties should be clarified, and the differences of responsibility between the responsible parties should be explained to avoid the recovery of the responsible persons in the future. Disagreement and second lawsuit.

\section{Conclusion}

In summary, the current joint responsibility in China's civil law is extremely important. Although many areas of civil and commercial law have been clearly defined for joint and several liabilities, and their content is maturing, the legal provisions involved in actual cases still need to be Further improvement, it is worth mentioning that the fundamental purpose of joint responsibility determination is to protect the legitimate rights and interests of creditors from being infringed. In the future process of building a rule of law society in China, the legal system will inevitably be continuously improved, more systematic and standardized. The joint liability in the civil and commercial law will also find an effective balance between the responsible and the right holders. On the basis of guaranteeing the legitimate rights and interests of the creditors, the rights of the responsible persons should be protected as much as possible, and the best interests of all the people should be protected to the greatest extent. Realize the legal approach of construction, safeguard the goal of socialist fairness and justice, and jointly build a harmonious and beautiful society.

\section{References}

[1] Liu Xue. Problems and Countermeasures in the Joint Liability of Civil and Commercial Laws. Modern Economic Information, Vol. 14 (2013) No.25, p. 343-343.

[2] Zhang Hang. Problems and Countermeasures in the Joint Liability of Civil and Commercial Laws. Legal System Expo, Vol. 15(2015) No.41, p. 263-263.

[3] Li Yu. Problems and Countermeasures in the Joint Liability of Civil and Commercial Laws. Journal of Jiangxi Youth Vocational College, Vol. 5 (2015) No. 18, p. 56-58.

[4] Liu Jun. A Random Discussion on the Identification and Handling of Joint Liability in China's National Commercial Law. Journal of Hubei Correspondence University, Vol. 7 (2014) No.26, p. 60-61.

[5] Wu Lan. Analysis of Problems and Countermeasures in the Joint Liability of Modern Civil and Commercial Laws. Legal System Expo, Vol. 17 (2015) No.36, p. 60-61.

[6] Gong Kai. Discussion on the problems and countermeasures in the joint responsibility of civil and commercial law. Legal System Expo, Vol.19 (2016) No.26, p.187-187.

[7] Zhan Ming. Analysis of the problems and countermeasures in the joint responsibility of modern civil and commercial law. Legal System Expo, Vol. 10 (2016) No.17, p. 287-287.

[8] Shi Yu. On the identification and treatment of joint liability in my national commercial law. Legal System and Society, Vol. 18 (2016) No.41, p. 12-13.

[9] Zhou Zhe. The Identification and Treatment of Joint Liability in China's National Commercial Law. Legal System Expo, Vol. 27 (2016) No.27, p. 153-153. 